ALCOHOL PROBLEMS 


\section{ALCOHOL PROBLEMS}

Reviews, Research and Recommendations

Edited by

David Robinson

Senior Lecturer in Sociology

Addiction Research Unit

Institute of Psychiatry

University of London 
(C) Selection and editorial matter David Robinson 1979

All rights reserved. No part of this publication may be reproduced or transmitted, in any form or by any means, without permission

First published 1979 by

THE MACMILLAN PRESS LTD

London and Basingstoke

Associated companies in Delhi Dublin

Hong Kong Johannesburg Lagos Melbourne

New York Singapore and Tokyo

Filmset in Great Britain by

Vantage Photosetting Co. Ltd.

Southampton and London

\section{British Library Cataloguing in Publication Data}

Alcohol problems

1. Alcoholism - Social aspects

I. Robinson, David, b. 1941

$362.2^{\prime} 92$

HV5035

ISBN 978-0-333-27568-9

DOI 10.1007/978-1-349-16190-4

ISBN 978-1-349-16190-4 (eBook)

This book is sold subject to the standard conditions of the Net Book Agreement

The paperback edition of this book is sold subject to the condition that it shall not, by way of trade or otherwise, be lent, resold, hired out, or otherwise circulated without the publisher's prior consent in any form of binding or cover other than that in which it is published and without a similar condition including this condition being imposed on the subsequent purchaser 


\section{Contents}

$\begin{array}{ll}\text { Introduction } & 1\end{array}$

Drinking and Social Life $\quad 11$

1 Alcohol and Culture David G. Mandelbaum 15

2 Three Centuries of Alcohol in Britain 22 Josephine A. Spring and David H. Buss

3 Drinking Schools Peter Archard 31

4 Changes in Skid Row Life David Levinson 39

Alcohol Problems and Alcoholism 47

5 Functions and Dysfunctions of Alcohol Irving Babow 51

6 Alcoholism is an Illness. Right? Wrong! Donald G. Finlay 56

7 The Alcohologist's Addiction David Robinson 63

8 Bad Habits are not Diseases Thomas S. Szasz 74

Teenage Drinking $\quad 79$

9 Teenage Drinking and Sociability Liz-Marie Kruse 81

10 Teenage Drinking: A Summary of Research Findings 88 Ronald L. Akers

11 A Perspective on Teenage Drinking Grace M. Barnes 93

12 Teenagers and Alcohol: Recommendations for Action 101 John Davies and Barrie Stacey

Women and Alcohol 109

13 The Women Alcoholic: A Review 113

Doreen F. Birchmore and Rodeen L. Walderman

14 Women and Problem Drinking: Notes on Beliefs and 121 Facts Eileen M. Corrigan

15 The Effects of Drinking on Offspring Rebecca H. Warner and Henry L. Rosett

16 The Alcoholic's Wife and Her Conflicting Roles 136 Carl Severin Albretson and Per Vaglum 
Alcohol and Work $\quad 147$

17 Drunken Sailors and Others Danielle Hitz 149

18 The Alcoholic Doctor Griffith Edwards 157

19 The Troubled Employee Approach Mark Keller(ed.) 162

20 Social Aspects of Industrial Alcoholism Programmes 172 Eero Lahelma

Drinking and Driving $\quad 179$

21 Normal Drinking and Normal Driving $\quad 181$ James G. Rankin

22 Drinking and Driving after it's Legal to Drink at 18. Is the Problem Real? Richard Zylman

23 Teenage Driver Fatalities Following Reduction in the Legal Drinking Age Ellen M. Naor and Raymond D. Nashold

24 Alcohol Safety Action Project and the Courts Gary J. Scrimgeour

Prevention and Public Health

25 The Prevention of Alcoholism Paul C. Whitehead 217

26 Alcohol Control Policies 227 World Health Organization

27 Effects of Liberalising Alcohol Control Measures 232 Paul C. Whitehead

28 Alcoholism Treatment in Antiquity and Utopia Griffith Edwards 


\section{Acknowledgements}

The author and publishers wish to thank the following who have kindly given permission for the use of copyright material:

Alcoholics Recovery Project for 'Drinking Schools' from The Bottle Won't Leave You by Peter Archard

Grace M. Barnes for the article 'A Perspective on Drinking Among Teenagers'

Irving Babow for his paper 'Functions and Dysfunctions of Alcohol'

Doreen M. Birchmore, Rodeen Walderman, and The Ontario Psychological Association for the article 'The Woman Alcoholic'

The Controller of Her Majesty's Stationery Office for use of 'Recommendations for Actions' by Davies and Stacey from Teenagers and Alcohol, Vol. II

Griffith Edwards and The Lancet for the paper 'The Alcoholic Doctor (1975)'

Jules Feiffer for the cartoon from the Observer Colour Magazine 1973

Field Newspaper Syndicate for the cartoon the 'Wizard of Id'

Health and Welfare for the article 'Alcoholism is an Illness: Right? Wrong?' by Donald G. Finlay from Canada's Mental Health, Vol. 22, No. 4, 1974

The Journal of Alcohol and Drug Education for extracts from 'Teenage Drinking: A Survey of Action Programs' by Ronald Akers, and 'Drinking and Driving After It's Legal To Drink at 18. Is the Problem Real' by Richard Zylman

The Journal of Drug Issues for extracts from 'Alcohol Safety Action Project and the Courts' by Gary J. Scrimgeour

Eero Lahelma for his paper 'Social Aspects of Industrial Alcoholism Programs'

London Express News and Feature Services for two cartoons from The Sun, 8 December 1973 and 5 May 1975, also a cartoon from the Evening Standard 1973 
The Medical Journal of Australia for the article 'The Effects of Alcohol on Driving Efficiency' by James G. Rankin

Mirror Group Newspapers Limited for the cartoon from the Daily Mirror, 5 October 1974

The National Institute on Alcohol Abuse and Alcoholism for the use of 'The Troubled Employee Approach' edited by Mark Keller from Alcohol and Health: New Knowledge, and 'Alcohol Treatment in Antiquity and Utopia' by Griffith Edwards from the Proceedings of the Second Annual Alcoholism Conference of the National Institute on Alcohol Abuse and Alcoholism

The National Safety Council for the article 'Teenage Driver Fatalities Following Reduction in the Legal Drinking Age' by Ellen M. Naor and R. D. Nashold published in the Journal of Safety Research, Vol. 7, No. 2, a National Safety Council publication

Nature, for the article 'Three Centuries of Alcohol in Britain' by Jospehine A. Spring and David M. Boss

Pergamon Press Limited for 'Effects of Liberalising Alcohol Control Measures' by Paul C. Whithead from Addictive Behaviours 1976

Plenum Publishing Corporation for use of 'Changes in Skid Row Life' by David Levinson from Urban Anthropology

Sage Publications Inc., and Liz-Marie Kruse for extracts from 'Teenage Drinking and Sociability'

The Scandinavian Journal of Social Medicine for the article 'The Alcoholic's Wife and her Conflicting Roles' by Carlo Albretsen and Per Vaglum

Share for the cartoon by Ged Melling published by Alcoholics Anonymous, May 1977

Spectrum Publications Inc. for the use of 'Women and Problem Drinking' by Eileen M. Corrigan and 'The Prevention of Alcoholism' by Paul C. Whitehead, from Addictive Diseases: An International Journal

Professor Thomas S. Szasz and The Lancet for the article 'Bad Habits are not Diseases'

The University of Chicago Press for use of extracts from 'Alcohol and Culture' by David G. Mandelbaum

The World Health Organization for extracts from 'Alcohol Control Policies' from WHO Chronicle, Vol. 30, June 1976 